\title{
Analisis kebutuhan pemberdayaan ibu rumah tangga miskin melalui usaha kerajinan tangan khas Gorontalo "Mohalamu Tiohu"
}

\author{
Lian Gafar Otaya *, Siti Asiah Tjabolo, Rahmin Talib Husain \\ Fakultas Ilmu Tarbiyah dan Keguruan, IAIN Sultan Amai Gorontalo. \\ Jalan Gelatik No. 1, Kota Gorontalo, Indonesia \\ * Corresponding Author. Email: lianotaya82@iaingorontalo.ac.id \\ Received: 27 October 2018; Revised: 13 March 2019; Accepted: 4 April 2019
}

\begin{abstract}
Abstrak
Penelitian ini bertujuan untuk menganalisis kebutuhan pemberdayaan ibu rumah tangga miskin melalui usaha kerajinan tangan khas Gorontalo yang dikenal dengan "Mohalamu Tiohu" atau anyaman mendong sebagai upaya pendampingan dengan menggunakan pendekatan Participatory Action Research (PAR) melalui 4 strategi yaitu: seleksi wilayah sasaran program, sosialisasi program, pelaksanaan program, monitoring dan evaluasi program. Data dikumpulkan melalui teknik observasi, Focused Group Discussion (FGD), wawancara dan teknik dokumentasi. Hasil temuan diperoleh permasalahan yang dihadapi adalah pengetahuan tentang desain produk dan pemasaran masih sangat terbatas, usahanya masih bersifat industri rumah, padahal mereka tergolong terampil dalam membuat berbagai jenis kerajinan tangan dalam jumlah banyak, tidak memiliki modal usaha, penghasilannya tidak sebanding dengan waktu dan tenaganya, padahal sifat bahan baku mudah didapatkan dan mampu mengikuti trend dengan teknik dasar menganyam yang hanya dapat dilakukan secara manual. Untuk starategi pengembangannya diperlukan adanya pembinaan secara berkala dan pemberian modal usaha secara merata kepada semua kelompok pengrajin ibu rumah tangga miskin, mempatenkan hasil karya dan menggalakkan kecintaan masyarakat terhadap kerajinan tersebut.
\end{abstract}

Kata Kunci: pemberdayaan, ibu rumah tangga miskin, participatory action research

\section{The need analysis of poor housewives empowerment in the development of Gorontalo special handicraft business "Mohalamu Tiohu"}

\begin{abstract}
This study aims to analyze the needs of poor housewives through the development of Gorontalo's special handicraft product design which is well known as "Mohalamu Tiohu" or mendong (Fimbrystlis Globulosa) plait as the guidance effort. The method used in this research was Participatory Action Research (PAR) through the observation and Focused Group Discussion (FGD). Based on the finding of this research, the problems faced by craftsman were the limited knowledge about product design and marketing, the problem that the business still in home business scale, there was no enough venture capital, the income was not comparable with the time and effort that they used. This fact was very ironic where the raw material was very easy to be found and also it was able to follow the current trend by using plait basic technique which could only be done manually. For the business development, it was urgently needed the continual guidance and the giving of venture capital evenly to the all craftsman group of poor housewives. Besides that, it was important to the craftsman to have patent and improved public love to their craft product.
\end{abstract}

Keywords: empowerment, poor housewives, the need analysis, participatory action research

How to Cite: Otaya, L., Tjabolo, S., \& Husain, R. (2019). Analisis kebutuhan pemberdayaan ibu rumah tangga miskin melalui usaha kerajinan tangan khas Gorontalo "Mohalamu Tiohu". JPPM (Jurnal Pendidikan dan Pemberdayaan Masyarakat), 6(1), 61-77. doi:https://doi.org/10.21831/jppm.v6i1.21736

do) https://doi.org/10.21831/jppm.v6i1.21736 


\section{JPPM (Jurnal Pendidikan dan Pemberdayaan Masyarakat), 6 (1), 2019 - 62}

Lian Gafar Otaya, Siti Asiah Tjabolo, Rahmin Talib Husain

\section{PENDAHULUAN}

Kemiskinan hingga saat ini tetap menjadi masalah kompleks dan menjadi masalah global yang dihadapi hampir semua negara serta menjadi masalah besar di dunia (Ahmadi, 2012, Armoyu, 2013). Berbagai upaya dan program kebijakan telah dilakukan untuk mengentaskan trend kemiskinan, namun tingkat kemiskinan hingga saat ini termasuk di Indonesia masih cenderung tinggi, karena permasalahan kemiskinan bersifat multi dimensional dan semakin disadari tidak hanya sekedar masalah ekonomi keuangan namun juga ketidakberdayaan masyarakat (Asril, 2013). Kesulitan untuk memenuhi kebutuhan hidup yang dialami oleh masyarakat menimbulkan kemiskinan (Wesa \& Suryono, 2014). Umumnya kemiskinan selalu mengarah kepada tingkat kesejahteraan masyarakat yang rendah (Harahap, 2018).

Kemiskinan salah satunya dipengaruhi oleh ketidakberdayaan masyarakat ditandai dengan lemahnya daya dukungan, daya dorong nilai kultural terhadap usaha peningkatan kondisi kehidupannya (Ras, 2013). Selain itu rendahnya penghasilan masyarakat membuat mereka tidak mampu memenuhi kebutuhan hidup dan pasrah akan keadaan yang ada. Pemberdayaan masyarakat merupakan salah satu alternatif yang menghendaki agar masyarakat mampu mandiri dalam memenuhi kebutuhan hidupnya (Asfi \& Wijaya, 2015).

Konsep pemberdayaan dalam wacana masyarakat selalu dihubungkan dengan konsep mandiri, partisipasi, jaringan kerja, dan keadilan (Prihatin \& Fauziah, 2013). Sementara pemberdayaan dalam konteks kemiskinan adalah suatu kondisi yang penting untuk memperbaiki kehidupan masyarakat miskin dari perspektif ekonomi, yang berfokus terutama pada mereka yang mampu mengambil keputusan dan membuat pilihan yang strategis (Alvarez, van Leeuwen, MontenegroMontenegro, \& van Vugt 2018). Menurut Armoyu (2013) pemberdayaan adalah serangkaian kegiatan pembangunan aset dan kapasitas masyarakat yang memungkinkan masyarakat itu berkemampuan untuk memilih dan menentukan tindakan-tindakan ke arah pencapaian tujuan hidupnya, termasuk dalam memberdayakan ibu rumah tangga miskin di salah satu desa di Kabupaten Bone Bolango Provinsi Gorontalo yaitu Desa Bulotalangi Timur.

Sehubungan dengan pentingnya program pemberdayaan tersebut, diperlukan adanya analisis kebutuhan untuk memberdayakan ibu rumah tangga miskin di Desa Bulotalangi Timur yang terletak di sebelah timur Kecamatan Bulango Timur yang jaraknya $\pm 1,5 \mathrm{~km}^{2}$ dari pusat kecamatan dengan luas wilayah $\pm 3,2 \mathrm{~km}^{2}$. Desa ini memiliki banyak potensi untuk diberdayakan baik dari sektor pertanian, perkebunan, peternakan, perdagangan, jasa, maupun industri kerajinan tangan. Program pemberdayaan yang dilakukan difokuskan pada pengembangan usaha kerajinan tangan khas Gorontalo "mohalamo tiohu" bagi ibu-ibu rumah tangga pengrajin yang hidup di bawah garis kemiskinan. Kerajinan tangan ini terbuat dari anyaman mendong yang lebih dikenal masyarakat Gorontalo dengan istilah "tiohu".

Kerajinan tangan "mohalamo tiohu" banyak ditekuni sebagai sumber penghasilan dan kehidupan ibu rumah tangga miskin di Desa Bulotalangi Timur. Namun hingga kini masyarakat Gorontalo hampir tidak mengenal dan kurang berminat terhadap kerajinan ini terutama sebagian masyarakat perkotaan yang cenderung menyukai produk luar atau yang dihasilkan pabrik. Perkembangan dan perubahan gaya hidup masyarakat modern saat ini yang lebih senang membeli barangbarang mewah, eksklusif dan elegan, atau adanya kecenderungan pola mengkonsumsi masyarakat perkotaan yang lebih menyukai produk impor dibanding produk local atau berbahan baku tradisional, telah mengubah citra produk kerajinan anyaman mendong ini kurang diminati oleh masyarakat dan pasar. Hal ini yang menyebabkan kerajinan tangan tersebut tidak mampu bersaing, sehingga kurang dapat diterima di masyarakat. Sebagai upaya meningkatkan produksi dan mempertahankan kerajinan tangan khas Gorontalo "mohalamo tiohu" kembali diterima masyarakat, perlu mendapatkan dukungan melalui program pendampingan bagi ibu rumah tangga pengrajin kerajinan tersebut, terutama dalam upaya pengembangan desain produknya menjadi berbagai macam jenis 


\section{JPPM (Jurnal Pendidikan dan Pemberdayaan Masyarakat), 6 (1), 2019 - 63}

Lian Gafar Otaya, Siti Asiah Tjabolo, Rahmin Talib Husain

kerajinan anyaman yang memiliki daya jual yang sangat tinggi seperti: tas, topi, dompet, tempat tisu, sandal, bingkai foto, taplak meja, tempat sampah, kaligrafi dan sebagainya, dengan mencoba mengikuti trend pasar dan mengenalkan berbagai bentuk varian atau desain anyaman mendong yang lebih menarik dan unik. Oleh karena itu, penting dilakukan analisis kebutuhan untuk memberdayakan Ibu rumah tangga miskin yang menjadi sasaran utama dampingan, sehinga mereka mampu menggali dan mengidentifikasi permasalahan serta mencari pemecahan masalah karena mereka tahu persis apa yang mereka butuhkan dan harapkan ke arah pencapaian tujuan hidup yang lebih baik.

\section{METODE}

Penelitian ini secara metodologis ditinjau dari jenis data termasuk penelitian kualitatif. Penelitian ini menggunakan pendekatan Participatory Action Research (PAR) sebagai strategi pemberdayaan yang dilakukan untuk mencapai kondisi yang diharapkan. PAR merupakan salah satu jenis penelitian kualitatif yang melibatkan tindakan peneliti dan anggota masyarakat atau organisasi yang berusaha untuk memperbaiki situasi mereka (Macdonald, 2012). Hal ini menunjukkan bahwa PAR memberikan solusi dalam menemukan upaya-upaya yang perlu dilakukan dalam mewujudkan perubahan baru pada masyarakat yang sesuai dengan kondisi dan kebutuhannya.

PAR disebut sebagai proses penyelidikan sosial yang edukatif dan dinamis untuk mengambil tindakan dalam mengatasi masalah atau untuk terlibat dalam aksi sosial (Koch, Selim, \& Kralik, 2002). Menurut Chevalier \& Bukles (2013, p. 9) PAR mengintegrasikan tiga komponen penting yaitu partisipasi (participation), tindakan (action), dan penelitian (research) sebagai upaya memberikan kontribusi dalam proses menemukan solusi perubahan sistem sosial (komunitas) untuk bertindak berdasarkan faktor-faktor kompleks yang berpengaruh pada ketidakberdayaan hidup yang tidak manusiawi sejalan dengan gerakan revolusi industri modern. Hubungan tiga komponen tersebut, oleh Chevalier \& Bukles (2013, p. 10) diilustrasikan pada Gambar 1.

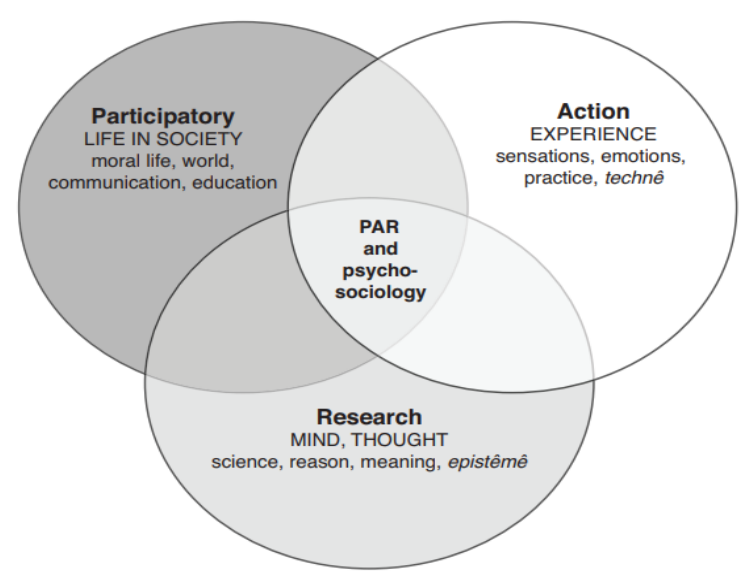

Gambar 1. Participation, Action, Research

(Chevalier \& Bukles (2013, p. 10)

Penelitian ini mendorong praktisi untuk berpartisipasi dalam mengembangkan bentuk-bentuk aksi dan interaksi untuk mengembangkan masyarakat, karena penelitian ini umumnya memiliki agenda aksi demi reformasi yang diharapkan dapat mengubah kehidupan para partisipan, institusi-institusi di mana mereka hidup dan bekerja (Kemmis, Taggart \& Nixon, 2013, p. 5, Darwis, 2016,). Selain itu, PAR berakar pada prinsip-prinsip inklusi (desain penelitiannya melibatkan orang, proses, dan hasil); adanya partisipasi; menghargai semua pendapat komunitas; dan adanya hasil pada perubahan yang berkelanjutan (Kidwai, et.al., 2017, p. 14). Berbagai pendapat tersebut, menunjukkan bahwa PAR adalah proses dan praktik penelitian yang diarahkan pada perubahan sosial dari para partisipan atau peserta yang dilibatkan secara individu dalam komunitas, berorientasi aksi dan interpretatif dalam mengubah kehidupan para partisipan sesuai dengan kondisi dan kebutuhan yang diharapkan.

Dengan demikian pendekatan PAR dipilih sesuai dengan tujuan diadakan program pemberdayaan ini tercapainya kondisi ideal komunitas dampingan yang berdaya melalui pengembangan desain produk usaha kerajinan tangan anyaman khas Gorontalo "Mohalamu Tiohu". Keberhasilan pemberdayaan ini sangat tergantung dari strategi yang dilakukan untuk mewujudkan kondisi yang diharapkan dari sasaran utama dampingan. Menurut Hadiyanti (2011) strategi dalam pemberdayaan dilakukan melalui beberapa tahapan yaitu: seleksi wilayah sasaran, sosialisasi pemberdayaan, pelaksanaan prog- 
JPPM (Jurnal Pendidikan dan Pemberdayaan Masyarakat), 6 (1), 2019 - 64

Lian Gafar Otaya, Siti Asiah Tjabolo, Rahmin Talib Husain

ram pemberdayaan, monitoring dan evaluasi penyelenggaraan program pemberdayaan. Selanjutnya menurut Wrihatnolo \& Dwidjowito membagi tiga tahapan strategi pemberdayaan (Wahyuni, 2018) yaitu: tahap penyadaran, tahap pengkapasitasan atau disebut dengan capacity building, dan tahap pendayaan yaitu masyarakat diberikan daya, otoritas atau peluang untuk berkembang mencapai kemandirian. Mengacu kepada kedua pendapat ini, maka strategi yang akan dilakukan dalam program pemberdayaan ini, yaitu: (1) seleksi wilayah sasaran program; (2) sosialisasi program pemberdayaan, (3) pelaksanaan program pemberdayaan dan (4) monitoring dan evaluasi program pemberdayaan.

Sasaran utama pemberdayaan yang dimaksud dalam penelitian ini adalah para ibu-ibu rumah tangga yang tergolong miskin dan masih usia produktif memiliki keahlian dalam mengayam mendong (mohalamu tiohu). Adapun jumlah ibu rumah tangga miskin yang dilibatkan dalam program pendampingan di Desa Bulotalangi Timur Kabupaten Bone Bolango Provinsi Gorontalo berjumlah 20 orang ibu rumah tangga yang sudah lama menjadi pengrajin kerajinan ini. Ibu rumah tangga tersebut ditetapkan secara partisipatif bersedia meluangkan waktunya untuk mengikuti program ini, serta mendampingi kelompok-kelompok ibu rumah tangga lainnya yang dibentuk sebagai sasaran utama dampingan dari program pemberdayaan ini.

Data penelitian ini dikumpulkan melalui teknik observasi lapangan, Focused Group Discussion (FGD), wawancara dan teknik dokumentasi. Menurut Gay, Mills, \& Airasian (2012, p. 210) semua teknik pengumpulan jenis data yang digunakan dalam penelitian kualitatif memiliki aspek kunci secara umum pada analisisnya terutama tergantung pada keterampilan integratif dan interpretatif dari peneliti, interpretasi diperlukan karena data yang dikumpulkan kaya akan rincian. Kedudukan strategis dari penelitian ini dapat memberi konstribusi positif dalam menganalisis kebutuhan ibu rumah tangga miskin yang menjadi sasaran utama dampingan untuk mengembangkan desain produk usaha kerajinan tangan anyaman khas Gorontalo "mohalamu tiohu".

Teknik analisis data dalam penelitian terdiri dari alur kegiatan yang terjadi secara bersamaan meliputi reduksi data, penyajian data, dan penarikan kesimpulan. Menurut Miles, Humerman, \& Saldana (2014, p. 33) bahwa aktivitas dalam analisis data kualitatif secara interaktif dan berlangsung secara terus-menerus pada setiap tahap penelitian hingga sampai tuntas, dan datanya sampai jenuh. Dengan demikian, untuk melakukan penarikan kesimpulan, diperoleh dari kegiatan refleksi sebagai proses analisis akhir dari hasil perolehan data otentik di lapangan untuk mendalami kebutuhan ibu rumah tangga miskin yang menjadi sasaran utama dampingan, sehingga dapat menemukan strategi pemberdayaan yang sesuai kondisi dan kebutuhannya untuk mengembangkan desain produk usaha kerajinan tangan anyaman khas Gorontalo "mohalamu tiohu”.

\section{HASIL DAN PEMBAHASAN}

\section{Strategi Pemberdayaan}

Kerajinan tangan khas Gorontalo "mohalamo tiohu" menjadi sumber penghasilan dan kehidupan ibu rumah tangga miskin, khususnya di salah satu desa yang menjadi sasaran utama dampingan ini yaitu di Desa Bulotalangi Timur Kabupaten Bone Bolango Provinsi Gorontalo. Desa ini memiliki penduduk berjumlah 832 jiwa yang terdiri dari laki-laki berjumlah 412 jiwa dan perempuan berjumlah 420 jiwa yang tersebar pada 214 kepala keluarga (kk). Dari jumlah kepala keluarga tersebut, hanya terdapat 39 KK yang tergolong mampu, selebihnya terdapat 49 KK tergolong miskin, dan 125 KK tergolong sangat miskin. Hal ini menggambarkan bahwa sebagian besar masyarakat di Desa Bulotalangi Timur tergolong miskin dan memprihatinkan, karena sebagian besar mata pencaharian mereka bersumber dari pekerjaan sebagai buruh tani dengan tingkat pendidikan tidak tamat SD, sebagaimana disajikan pada Tabel 1. 
JPPM (Jurnal Pendidikan dan Pemberdayaan Masyarakat), 6 (1), 2019 - 65

Lian Gafar Otaya, Siti Asiah Tjabolo, Rahmin Talib Husain

Tabel 1. Kondisi Masyarakat Dampingan

\begin{tabular}{|c|c|c|c|}
\hline \multicolumn{2}{|c|}{ Kondisi Masyarakat Menurut Mata Pencaharian } & \multicolumn{2}{|c|}{ Kondisi Masyarakat Menurut Tingkat Pendidikan } \\
\hline Mata Pencaharian & Jumlah (Jiwa) & Tingkat Pendidikan & Jumlah (Jiwa) \\
\hline Buruh Tani & 175 & Tidak/Belum Sekolah & 98 \\
\hline Petani & 98 & Tidak Tamat SD & 380 \\
\hline Peternak & 60 & Tamat SD & 188 \\
\hline Pedagang & 8 & Tamat SMP & 84 \\
\hline PNS & 10 & Tamat SMU & 67 \\
\hline Jasa & 30 & Tamat Perguruan Tinggi & \\
\hline TNI/Polri & 1 & & 10 \\
\hline Lain-Lain & 79 & & \\
\hline
\end{tabular}

Berdasarkan kondisi masyarakat tersebut, upaya pendampingan di Desa Bulotalangi Timur perlu dilakukan agar mampu memberdayakan masyarakat melalui pengembangan kerajinan tangan khas Gorontalo "mohalamo tiohu” menuju perubahan hidup yang sesuai dengan kondisi dan kebutuhannya, sehingga diharapkan dapat memberikan kontribusi yang besar bagi peningkatan kesejahteraan hidup mereka dan mendukung laju pertumbuhan pembangunan dalam mendukung potensi desa yang dapat menjamin kemajuan ekonomi dan kestabilan masyarakatnya. Hal ini sejalan dengan visi dari Desa Bulotalangi Timur “Terwujudnya masyarakat Desa Bulotalangi Timur yang maju, mandiri, religius yang dilandasi oleh kekeluargaan dan kerukunan menuju kehidupan yang sejahtera". Lebih lanjut visi tersebut dijabarkan pada salah satu misi yang diusung pemerintah Desa Bulotalangi Timur bidang pemberdayaan "mengembangkan industri rumah tangga untuk meningkatkan usaha ekonomi produktif'. Oleh karena itu, diharapkan melalui program pendampingan ini, visi dan misi tersebut akan terwujud.

Dengan demikian pemberdayaan ibu rumah tangga miskin yang menjadi sasaran utama dampingan melalui pengembangan usaha kerajinan tangan khas Gorontalo "mohalamu tiohu" di Desa Bulotalangi Timur Bone Bolango merupakan salah satu upaya pendampingan yang perlu dilakukan dalam membantu ibu rumah tangga miskin sebagai pengrajin kerajinan tersebut, agar membawa dampak multiplier yang luas terhadap pertumbuhan perekonomian ibu rumah tangga miskin pada khususnya dan masyarakat umumnya. Selain itu, diharapkan menum- buhkan inisiatif atau prakarsa untuk menciptakan lapangan kerja baru sesuai dengan potensi yang ada di Desa Bulotalangi Timur melalui pengembangan produk kerajinan yang memenuhi selera dan kebutuhan konsumen atau pasar. Mengingat suatu produk anyaman mendong (mohalamu tiohu) yang dikembangkan harus mempunyai keunggulan supaya bisa bersaing dan memiliki nilai jual yang tinggi.

Menurut Darwis (2016) keberhasilan pemberdayaan masyarakat memiliki empat dimensi kekuasaan, yaitu: (1) kekuasaan dalam (power within); (2) kekuasaan untuk (power to); (3) kekuasaan atas (power over), dan (4) kekuasaan dengan' (power with). Keempat dimensi tersebut menunjukkan keberdayaan masyarakat terkait dengan kemampuan ekonomi, kemampuan mengakses manfaat kesejahteraan, dan kemampuan kultural dan politis. Dari keempat dimensi yang ingin dicapai dalam program pemberdayaan ini difokuskan pada dua dimensi yaitu kemampuan ekonomi dan kemampuan mengakses manfaat kesejahteraan dari hasil dampingan yang dilakukan.

Berdasarkan penelitian yang dilakukan diperoleh hasil temuan yang dapat menggambarkan kondisi ibu rumah tangga miskin yang menjadi sasaran utama dampingan saat ini, dengan melakukan strategi pemberdayaan sebagai berikut:

\section{Seleksi Wilayah Sasaran}

Wilayah sasaran yang menjadi lokasi program pemberdayaan yaitu Desa Bulotalangi Timur Bone Bolango, memenuhi kriteria pemilihan lokasi berdasarkan tujuan dari program pemberdayaan ini, karena hasil temuan awal terungkap bahwa di desa ini 
JPPM (Jurnal Pendidikan dan Pemberdayaan Masyarakat), 6 (1), 2019 - 66

Lian Gafar Otaya, Siti Asiah Tjabolo, Rahmin Talib Husain

terdapat banyak ibu rumah tangga miskin yang memiliki keahlian sebagai pengrajin anyaman mendong (mohalamu tiohu), namun belum diberdayakan karena dipengaruhi berbagai faktor yang membuat mereka tidak mampu berkembang dan berkreasi sesuai dengan kemampuan yang mereka miliki terutama dalam menghasilkan berbagai jenis produk kerajinan anyaman mendong (tiohu). Hal ini secara garis besar diperoleh hal menarik dari hasil temuan FGD dengan ibu rumah tangga miskin yang menjadi sasaran utama dampingan bahwa kerajinan tangan khas Gorontalo "mohalamo tiohu" hanya dikreasikan menjadi tikar, seperti yang ditunjukkan pada Gambar 2.

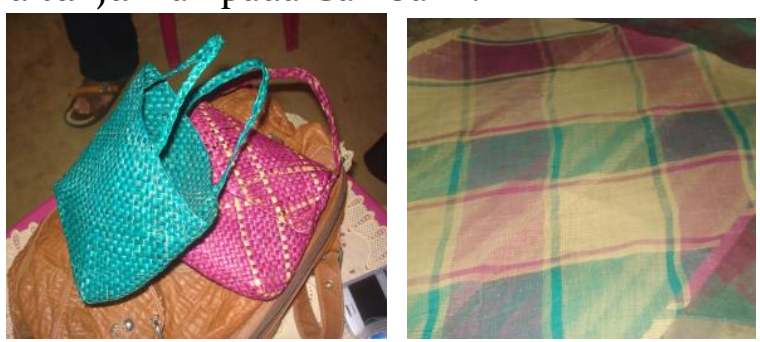

Gambar 2. Hasil Kerajinan Pengrajin

Berdasarkan hasil temuan tersebut, menunjukkan belum pernah dibuat produk yang lain, yang memiliki daya tarik dan nilai jual tinggi seperti: tas, topi, dompet, tempat tisu, sandal, bingkai foto, taplak meja, tempat sampah, kaligrafi dan sebagainya. Padahal di Desa Bulotalangi Timur ini terdapat kurang lebih 20 orang ibu-ibu rumah tangga yang tergolong terampil dan masih usia produktif memiliki keahlian dalam mengayam mendong (mohalamu tiohu), tidak diberdayakan. Setiap harinya mereka menghabiskan waktu dengan sia-sia, karena tidak ada pekerjaan sampingan selain mengurus rumah tangga. Sementara tuntutan kebutuhan hidup keluarga sangat banyak mulai dari makan seharihari, menyekolahkan anak, membeli seragam dan perlengkapan sekolah dan keperluan mendesak lainnya. Bahkan rata-rata mereka seringkali terlambat memasukkan anaknya duduk di bangku sekolah, hanya karena alasan tidak ada biaya, tidak ada uang untuk membeli seragam maupun perlengkapan sekolah lainnya.

Dengan demikian, secara umum kondisi yang diharapkan dari ibu rumah tangga miskin yang menjadi sasaran utama dam- pingan adalah terwujudnya ibu rumah tangga yang berdaya secara ekonomi dan memiliki kemandirian dalam hal kemampuan dan kemauan untuk mengembangkan diri. Mengingat harapan dari ibu rumah tangga miskin yang menjadi sasaran utama dampingan berharap dapat mengembangkan berbagai desain produk kerajinan tangan anyaman khas Gorontalo "mohalamu tiohu" seperti: tas, topi, dompet, tempat tisu, sandal, bingkai foto, taplak meja, tempat sampah, kaligrafi dan sebagainya. Sedangkan secara spesifik, kondisi yang diharapkan adalah: (1) ibu rumah tangga miskin yang menjadi sasaran utama dampingan memiliki pengetahuan dan kemampuan memadai dalam membuat berbagai jenis kerajinan tangan anyaman khas Gorontalo "mohalamu tiohu" dengan model yang bervariasi dan dalam jumlah yang banyak; (2) dengan mengembangkan berbagai desain produk kerajinan tangan anyaman khas Gorontalo "mohalamu tiohu" seperti: tas, topi, dompet, tempat tisu, sandal, bingkai foto, taplak meja, tempat sampah, kaligrafi dan sebagainya yang memiliki daya jual tinggi, diharapkan mampu membawa perubahan pada kehidupan ekonomi masyarakat di Desa Bulotalangi Timur pada umumnya dan khususnya pada ibu rumah tangga miskin yang menjadi sasaran utama dampingan; (3) ibu rumah tangga miskin yang menjadi sasaran utama dampingan dapat mengakses pinjaman modal untuk mengembangkan usaha mereka; (4) ibu rumah tangga miskin yang menjadi sasaran utama dampingan memiliki jiwa kemandirian dan wirausaha sehingga mampu mandiri secara ekonomi, seiring dengan berkembangnya usaha mereka dalam memproduksi berbagai jenis kerajinan tangan anyaman yang berbahan baku mendong (tiohu).

Sosialisasi Program Pemberdayaan

Sosialisasi program pemberdayaan dilakukan, agar maksud dan tujuan program pemberdayaan yang dilakukan melalui pengembangan usaha kerajinan tangan khas Gorontalo "mohalamu tiohu" di Desa Bulotalangi Timur Bone Bolango diketahui oleh ibu rumah tangga miskin yang menjadi sasaran utama dampingan. Esensi dari kegiatan ini adalah untuk melakukan penyamaan 
JPPM (Jurnal Pendidikan dan Pemberdayaan Masyarakat), 6 (1), 2019 - 67

Lian Gafar Otaya, Siti Asiah Tjabolo, Rahmin Talib Husain

persepsi maksud dan tujuan dari kegiatan pemberdayaan yang dilakukan dalam mengembangkan berbagai desain produk kerajinan anyaman mendong seperti: tas, topi, dompet, tempat tisu, sandal, bingkai foto, taplak meja, tempat sampah, kaligrafi dan sebagainya untuk mewujudkan kemandirian ibu rumah tangga miskin dalam merubah kehidupan ekonominya menjadi lebih baik dari sebelumnya.

Sosialisasi program pemberdayaan kepada sasaran utama dampingan ini sangat penting untuk dilakukan, sesuai dengan pendapat Hadiyanti (2011) kegiatan ini bermanfaat dapat menciptakan komunikasi serta dialog yang interaktif dengan masyarakat. Selain itu, meningkatkan pengertian pada masyarakat terkait program pemberdayaan yang akan dilakukan dan kegiatan ini sangat menentukan ketertarikan masyarakat untuk berperan dan terlibat didalam program pemberdayaan tersebut. Oleh karena itu, untuk sosialisasi program pemberdayaan ini dilakukan dengan tahapan yaitu: (1) menghadirkan semua ibu rumah tangga di Desa Bulotalangi Timur yang menjadi sasaran utama dampingan untuk menyampaikan maksud dan tujuan program pemberdayaan melalui pengembangan desain produk usaha kerajinan tangan anyaman khas Gorontalo "mohalamu tiohu"; (2) mengadakan pertemuan dengan masyarakat, aparat pemerintah dan tokoh masyarakat yang ada di desa tersebut untuk meminta izin dan dukungan dalam pelaksanaan program pemberdayaan serta mengidentifikasi kondisi sasaran utama dampingan; (3) melakukan kunjungan dan diskusi kelompok untuk menggugah kesadaran sasaran utama dampingan agar berpartisipasi aktif dalam program pemberdayaan yang dilakukan.

Pelaksanaan Program Pemberdayaan

Pelaksanaan program pemberdayaan ini, diawali dengan pembentukan kelompok dari ibu rumah tangga yang menjadi sasaran utama dampingan. Terkait dengan pembentukan kelompok dari program pemberdayaan ini, tersebar di empat dusun Desa Bulotalangi Timur, maka pembentukan kelompok dilakukan di masing-masing dusun yaitu Dusun I berjumlah 4 orang, Dusun II berjumlah 5 orang, Dusun III berjumlah 7 orang dan Dusun IV sejumlah 4 orang. Berdasarkan kegiatan tersebut, juga dilakukan pembagian jenis produk kerajinan anyaman mendong yang akan dibuat oleh masing-masing kelompok, agar masing-masing kelompok memiliki produk andalan dengan ciri khas produk yang berbeda. Adapun jenis produk kerajinan anyaman mendong (tiohu) yang akan dibuat dan dikembangkan pada masing-masing kelompok yang telah terbentuk adalah sebagai berikut.

Kelompok 1: Jenis produk kerajinan yang akan dikembangkan adalah sandal dengan beberapa varian mulai dari sandal main, sandal santai, sampai sandal hotel seperti yang ditunjukkan Gambar 3.
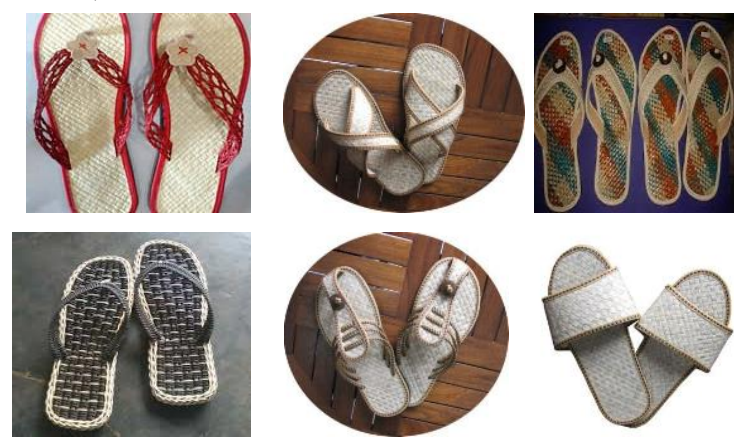

Gambar 3. Jenis Kerajinan Sandal

Kelompok 2: Jenis produk kerajinan yang akan dikembangkan terdiri dari: tas santai, tas seminar, dan tas make up, dompet seperti pada Gambar 3.
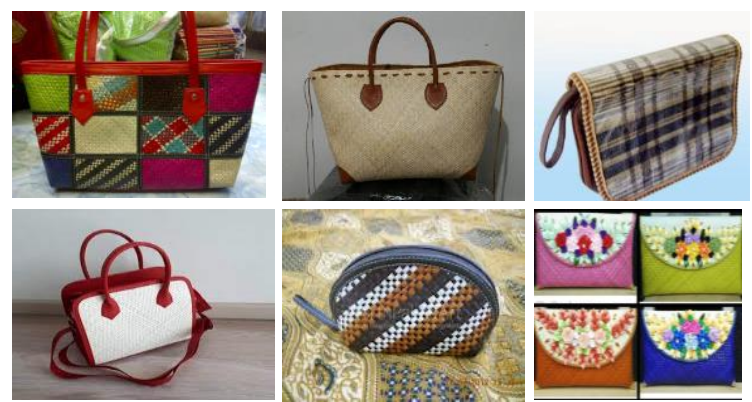

Gambar 3. Jenis Kerajinan Tas

Jenis produk lainnya yang akan dikembangkan pada Kelompok 2 adalah Kotak tisu yang dihasilkan berbagai bentuk anyaman dan corak warna yang berbeda dengan contoh produk seperti yang ditunjukkan pada Gambar 4 . 
JPPM (Jurnal Pendidikan dan Pemberdayaan Masyarakat), 6 (1), 2019 - 68 Lian Gafar Otaya, Siti Asiah Tjabolo, Rahmin Talib Husain

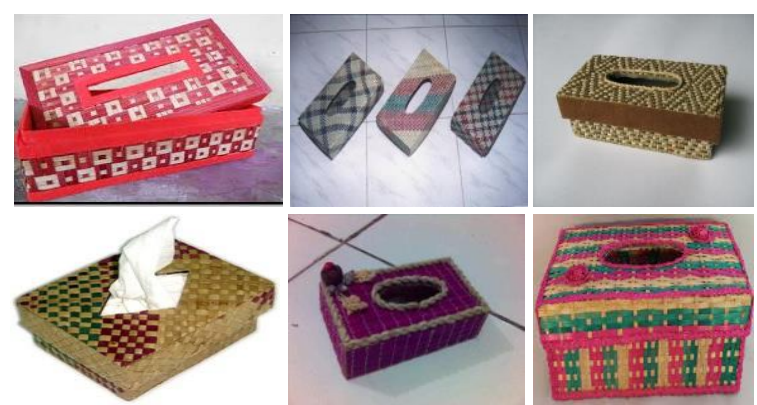

Gambar 4. Jenis Kerajinan Tempat Tisu

Kelompok 3: Jenis produk kerajinan tangan yang akan dikembangkan adalah berbagai hiasan seperti buku cacatan harian, taplak meja, tempat sampah, figura foto,dan lainlain seperti ditunjukkan pada Gambar 4.

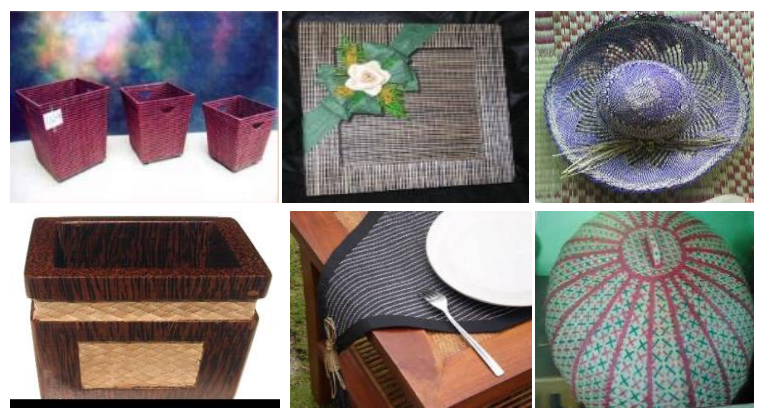

Gambar 5. Jenis Kerajinan Kelompok 3

Selanjutnya dilakukan pengembangan kapasitas dari sasaran utama dampingan melalui pemberian pengetahuan dan pendampingan pelatihan baik secara individu maupun kelompok tentang manajemen berwirausaha, peluang dan tantangan dalam berwirausaha serta kiat-kiat dalam mendesain produk yang mampu memiliki nilai jual tinggi. Selain itu, dirumuskan strategi pencapaian pengembangan usaha produk yang dilakukan, dengan membangun organisasi kelembagaan dengan sistem nilai yang ditaati bersama. Sebagaimana dikemukakan Wahyuni (2018) bahwa dalam program pemberdayaan, masyarakat penting dibuatkan wadah organisasi dalam pengkapasitasan sistem nilai yang harus dipatuhi semua pihak terkait untuk membantu mereka menyusun aturan main, seperti: peraturan usaha bersama, sistem dan prosedur usaha dan sebagainya.

Selanjutnya penguatan kapasitas sasaran utama dampingan melalui pemberian kredit modal yang dibutuhkan untuk mengembangkan usahanya. Menurut Wahyuni (2018) pemberian kedit modal usaha kepada masyarakat dampingan merupakan pemberian daya kepada mereka untuk berkembang mencapai kemandirian yaitu masyarakat dampingan yang mampu membangun dirinya dan memperbaiki kehidupannya melalui potensi yang dimiliki. Hal ini sangat tergantung dari seberapa besar wujud partisipasi yang diberikan oleh individu atau masyarakat dampingan dalam setiap tahapan kegiatan yang dilakukan tim fasilitator.

\section{Monitoring dan Evaluasi Program}

Keberhasilan suatu program pemberdayaan dapat diukur dan dinilai dari kegiatan monitoring dan evaluasi program. Menurut Hadiyanti (2011) monitoring dan evaluasi program pemberdayaan merupakan kegiatan yang sangat penting dilakukan dalam mengukur keberhasilan program pemberdayaan masyarakat, karena dengan adanya evaluasi, dapat diketahui sejauhmana efektivitas dan efisiensi program pemberdayaan yang dilakukan terhadap proses, pencapaian dan dampak proses pemberdayaan. Adapun aspek-aspek yang dimonitoring dan dievaluasi dalam program pemberdayaan ini masih sebatas pada komponen konteks, input, dan proses pelaksanaan, untuk evaluasi pada komponen pencapaian dan dampak proses pemberdayaan belum dapat dilakukan, karena dalam penelitian ini hanya mengidentifikasi kebutuhan ibu rumah tangga miskin yang menjadi sasaran utama dampingan dalam mengembangkan desain produk usaha kerajinan tangan anyaman khas Gorontalo "mohalamu tiohu".

Komponen konteks yang dievaluasi dalam program pemberdayaan ini meliputi aspek: tujuan program, keadaan geografis, kebutuhan masyarakat yang menjadi sasaran dampingan dari program, dukungan atau partisipasi masyarakat pada perumusan program pemberdayaan, aspirasi masyarakat terhadap perencanaan program dan status sosial ekonomi masyarakat terkait pelaksanaan pemberdayaan.

Berdasarkan hasil evaluasi dari komponen konteks pada aspek tujuan program sudah sesuai dengan tingkat kepentingan dan kebutuhan masyarakat yang menjadi sasaran utama dampingan dengan selalu menjalin kerjasama dengan pemerintah setempat. 
JPPM (Jurnal Pendidikan dan Pemberdayaan Masyarakat), 6 (1), 2019 - 69

Lian Gafar Otaya, Siti Asiah Tjabolo, Rahmin Talib Husain

Pada aspek kondisi geografis sangat mendukung, karena masyarakat mendukung pelaksanaan program pemberdayaan ini secara positif yang ditunjukkan dari partisipasi dan keterlibatannya dalam setiap pertemuan yang diadakan mulai dari pembentukan kelompok dampingan hingga sosialisasi program. Aparat pemerintah, tokoh masyarakat dan masyarakat serta stakeholders terkait sangat mendukung pelaksanaan program pemberdayaan ini, karena mereka merasa ikut memiliki dan perhatian kepada masyarakat yang menjadi sasaran utama dampingan, dukungan iklim komunikasi dan hubungan yang baik dengan masyarakat, serta adanya keyakinan yang kuat dari masyarakat terhadap keberhasilan dari program pemberdayaan ini mampu membawa perubahan hidupnya ke arah yang lebih baik. Dengan demikian, secara keseluruhan daya dukung latar geografis terhadap keberlangsungan program pemberdayaan ini sangat baik.

Selanjutnya pada aspek kebutuhan masyarakat terhadap keberadaan program pemberdayaan ini juga sangat baik, karena motivasi ibu rumah tangga miskin yang menjadi sasaran utama dampingan pada program pemberdayaan ini sangat tinggi, yang dibuktikan dari kehadirannya pada setiap kunjungan atau undangan yang diberikan. Demikian halnya, pada aspek dukungan masyarakat secara umum sudah baik dalam mendukung pelaksanaan program pemberdayaan ini dalam bentuk usul, saran maupun kritik dalam perencanaan program pemberdayaan. Meskipun masih ada beberapa masyarakat dalam hal ini suami dari ibu-ibu rumah tangga yang menjadi sasaran utama dampingan masih terkesan setengah hati atau kurang percaya dengan keberhasilan program pemberdayaan ini. Namun sekecil apapun dukungan yang diberikan oleh masyarakat adalah sebagai bentuk partisipasi. Dukungan tersebut tidak hanya direpresentasikan dalam bentuk tenaga dan material, tetapi juga dukungan moril kepada ibu-ibu rumah tangga yang menjadi sasaran utama dampingan juga sangat bermakna bagi efektivitas pelaksanaan program pemberdayaan.

Selanjutnya pada aspek aspirasi masyarakat terhadap perencanaan program pem- berdayaan masih kurang, karena sebagian besar masyarakat memiliki tingkat pendidikan yang rendah yaitu tidak tamat SD, sehingga dalam menyampaikan aspirasi dan informasi sesuai dengan kebutuhan pengetahuannya masih terbatas. Sementara pada aspek status sosial dan ekonomi masyarakat memiliki pengaruh yang besar terhadap keberlangsungan program ini. Dengan membaiknya status sosial dan ekonomi masyarakat, cenderung ibu rumah tangga yang menjadi sasaran utama dampingan untuk mengembangkan usaha kerajinannya. Mengingat status sosial ekonomi sasaran dampingan rata-rata tergolong ekonomi menengah ke bawah, maka sangat membutuhkan program ini dalam meningkatkan kondisi perekonomiannya menuju kehidupan yang layak dan sejahtera.

Dengan demikan secara keseluruhan evaluasi pada komponen konteks ditinjau dari penilaian berdasarkan aspek maupun penilaian berdasarkan sumber data adalah berada pada kategori baik dalam mendukung pelaksanaan program pemberdayaan ibu rumah tangga miskin yang menjadi sasaran utama dampingan.

Evaluasi pada komponen input dari pelaksanaan program pemberdayaan ini, dilakukan untuk melihat kesiapan dari tim fasilitator dan para stakeholder yang memiliki peran aktif dalam pelaksanaan program. Kesiapan yang dievaluasi adalah kesiapan motivasi, kemampuan para pengelola program pemberdayaan dan kesiapan infrastruktur dan sistim administrasi pendukung kegiatan program pemberdayaan yaitu pada aspek organisasi pelaksana program berada pada kategori baik, karena tim fasilitator dampingan yang ditunjuk memiliki kapabilitas yang baik dalam menjalankan program yang sesuai dengan sistem pengelolaan yang efektif dan efisien.

Pada aspek sosialisasi program pemberdayaan juga berada pada kategori baik, sasaran program dan indikator keberhasilannya sangat penting untuk diketahui dan dipahami oleh sasaran utama dampingan, karena dari sanalah arah dukungan dan partisipasinya diberikan. Hal ini perlu mendapat perhatian dari fasilitator program untuk meningkatkan sosialisasi tujuan program pemberdayaan. 
JPPM (Jurnal Pendidikan dan Pemberdayaan Masyarakat), 6 (1), 2019 - 70

Lian Gafar Otaya, Siti Asiah Tjabolo, Rahmin Talib Husain

Pada aspek sumber daya hasil temuan berada pada kategori baik, karena keberadaan bahan baku utama "tanaman mendong" (tiohu) sangat tersedia dan mudah dibudidayakan. Selain itu, di desa ini terdapat 20 orang ibu rumah tangga miskin yang sudah lama menekuni usaha ini, meskipun hasil produksinya masih sangat terbatas. Hal ini didasarkan dari hasil temuan FGD yang menemukan bahwa ibu-ibu rumah tangga tersebut memiliki keterampilan dalam mengayam mendong (mohalamu tiohu), meskipun hanya dalam bentuk jenis anyaman tikar dan tas sederhana. Hal ini dipengaruhi oleh sumber dana, jumlah dana, usaha-usaha untuk memperoleh tambahan dana, serta penggunaannya yang belum efektif. Kalau dicermati berdasarkan hasil observasi keberadaan bahan baku utama mendong (tiohu) tergolong sangat cukup tersedia untuk mengembangkannya menjadi berbagai desain produk yang sesuai dengan kebutuhan pasar. Namun untuk peralatan dan bahan penunjang yang masih terbatas jumlahnya dan belum memadai, sehingga hal ini akan menjadi kendala para ibu rumah tangga dalam mengembangkan usahanya.

Evaluasi pada komponen pelaksanaan program pemberdayaan, berdasarkan hasil observasi, wawancara dan pencatatan dokumen, maka dapat dideskripsikan hasil evaluasi pelaksanaan program pemberdayaan ini ditinjau dari aspek proses pengambilan keputusan, pengelolaan kelembagaan dan pengelolaan program, proses kerjasama dan partisipasi, akuntabilitas, kemandirian, keterbukaan dan keberlanjutan yaitu:

Pada aspek proses pengambilan keputusan berdasarkan penilaian sasaran utama dampingan berada pada kategori baik. Artinya proses pengambilan keputusan dari segala atribut yang berkaitan dengan pelaksanaan program pemberdayaan sudah melibatkan stakeholders terkait. Aparat pemerintah, aparat desa, tokoh masyarakat, dan masyarakat yang menjadi sasaran utama dampingan menilai bahwa setiap keputusan yang diambil dalam pelaksanaan program pemberdayaan ini selalu berdasarkan hasil pertemuan/rapat baik berupa usul, kritik, pendapat dan lain-lain, bentuk pengambilan keputusan didasarkan atas asas musyawarah, mufakat dan demokratis. Hal ini sesuai dengan wawancara dengan aparat desa dan beberapa tokoh masyarakat mengemukakan secara garis besar bahwa dalam pembuatan dan perumusan rencana program pemberdayaan, tim fasilitator selalu mengundang mereka dalam rapat untuk merumuskan rencana program pemberdayaan yang sesuai dengan kondisi dan kebutuhan sasaran utama dampingan. Hal ini dibuktikan dengan dokumentasi tentang administrasi proses pengambilan keputusan, seperti: notulen rapat, dan hasil pembahasan dalam pengambilan keputusan tersedia secara lengkap.

Aspek proses pengelolaan program pemberdayaan secara kelembagaan dibentuk tim fasilitator program dan pembentukan ketua-ketua kelompok pada setiap dusun yang ada di Desa Bulatolangi Timur, hal ini untuk memudahkan garis koordinasi dalam memperlancar pelaksanaan program pemberdayaan. Mengenai pelaksanaan sosialisasi program diatur oleh tim fasilitator yang ditunjuk sebagai penanggungjawab program. Hal ini menjadi sangat penting dalam mempercepat pencapaian sasaran program pemberdayaan.

Mengenai proses kerjasama dan partisipasi dalam pelaksanaan program pemberdayaan ini juga berada pada kategori baik. Hal ini disebabkan karena adanya pengalaman tim fasilitator yang dilibatkan dalam mengelola program yang membutuhkan kerjasama dengan pihak terkait terutama pemerintah setempat. Oleh karena itu, proses kerjasama dan penggalangan partisipasi dari pihak pemerintah setempat terus-menerus diupayakan.

Aspek akuntabilitas, kemandirian dan proses keterbukaan juga berada pada kategori baik. Hal ini sesuai dengan wawancara dengan beberapa ibu rumah tangga yang menjadi sasaran utama dampingan mengungkapkan bahwa tim fasilitator selalu transparan dan terbuka dalam segala hal, sehingga menggugah kesadaran mereka untuk berpartisipasi sepenuhnya yang ditunjukkan dari kemauan mereka yang tinggi untuk melakukan perubahan pada diri mereka. 
JPPM (Jurnal Pendidikan dan Pemberdayaan Masyarakat), 6 (1), 2019 - 71

Lian Gafar Otaya, Siti Asiah Tjabolo, Rahmin Talib Husain

Analisis Kebutuhan

Berdasarkan strategi pemberdayaan ibu rumah tangga miskin yang dilakukan melalui pengembangan desain produk usaha kerajinan tangan anyaman mendong (mohalamu tiohu) di Desa Bulotalangi Timur Bone Bolango diperlukan suatu analisis untuk mengetahui gambaran mengenai kekuatan yang dimiliki dan kelemahan yang dihadapi (analisis internal), serta peluang dan tantangan (analisis eksternal) yang akan muncul yaitu sebagai berikut:

Analisis Internal

Analisis internal dilakukan untuk menemukan strategi yang perlu dilakukan dalam memberdayakan ibu rumah tangga miskin yang dilakukan dengan menganalisis kekuatan (strength) yang dimiliki dan kelemahan (weakness) yang dihadapi sesuai dengan kondisi dan kebutuhan dampingan dalam mengembangkan desain produk usaha kerajinan tangan anyaman mendong (mohalamu tiohu) di Desa Bulotalangi Timur Bone Bolango.

Berdasarkan hasil temuan yang diperoleh selama melakukan dampingan pada ibu rumah tangga miskin yang menjadi sasaran utama dari kegiatan ini, dapat diidentifikasi beberapa hal yang menjadi kekuatan dan kelemahan dari program dampingan yang dilakukan yaitu:

\section{Kekuatan (Strength)}

Pertama, lokasi Desa Bulotalangi Timur cukup strategis dan mudah untuk akses kendaraan. Selain itu, kondisi alam subur dan asri dikarenakan terletak di daerah pegunungan dan lembah dan dilalui sungai. Tersedianya infrastruktur berupa jalan raya yang menghubungkan Desa Bulotalangi Timur dengan Kecamatan Bulango Timur, Kabupaten Bone Bolango dan dengan Kota Gorontalo, serta jalan desa dalam kondisi baik untuk memudahkan akses dengan kelompok-kelompok yang menjadi sasaran utama dampingan. Pemilihan lokasi ini, sejalan dengan Hadiyanti (2011) bahwa pemilihan lokasi dampingan, penting dilakukan agar tujuan dalam memberdayakan masyarakat akan tercapai serta pemilihan lokasi dilakukan dengan sangat baik. Salah satu kriteria yang perlu diperhatikan dalam pemilihan lokasi dampingan adalah adanya masyarakat yang hidup dalam kondisi kekurangan (marjinal) dan kriteria ini terpenuhi, karena di Desa Bulotalangi Timur terdapat banyak ibu-ibu rumah tangga miskin yang terampil dalam membuat berbagai jenis kerajinan tangan dari anyaman mendong dan dalam jumlah banyak, namun tidak diberdayakan secara optimal dikarenakan faktor keterbatasan modal dalam mengembangkan usahanya.

Kedua, ketersedian bahan baku "tanaman mendong (tiohu)" yang mudah didapat dan sifat bahan sangat ramah lingkungan serta mudah dibudidayakan, sangat menunjang ibu rumah tangga miskin yang menjadi sasaran utama dampingan ini dalam mengembangkan usaha kerajinannya, karena bahan baku ini selalu tersedia dan tidak sulit untuk mendapatkannya.

Ketiga, usaha kerajinan ini perlu untuk dikembangkan, karena memiliki keunikan tersendiri dalam hal teknik produksi yaitu teknik dasar menganyam yang hanya dapat dilakukan secara manual, dan hal ini menjadi daya tarik dalam meningkatkan kualitas dan desain produk kerajinan ini agar memiliki nilai jual yang tinggi.

Keempat, tampilan visual (tekstur) dari produk kerajinan ini memiliki bentuk pola anyaman yang indah dan dikreasi dengan kombinasi warna yang menarik. Hal ini tentunya menjadi keunggulan dalam mengembangkan produk kerajinan dari ibu rumah tangga miskin tersebut, menuju ke arah perubahan yang diharapkan.

Kelemahan (Weakness)

Kelemahan yang dihadapi dalam memberdayakan ibu rumah tangga miskin yang menjadi sasaran utama dampingan adalah: Pertama, tingkat pendidikan rendah mengakibatkan pengetahuan mereka juga rendah terkait dengan program pemberdayaan. Faktor ini, tentunya mempengaruhi keberhasilan pemberdayaan yang dilakukan, sehingga perlu dilakukan sosialisasi program pemberdayaan. Hal ini sesuai pendapat Hadiyanti (2011) bahwa sosialisasi program pemberdayaan pada masyarakat diperlukan untuk 


\section{JPPM (Jurnal Pendidikan dan Pemberdayaan Masyarakat), 6 (1), 2019 - 72 \\ Lian Gafar Otaya, Siti Asiah Tjabolo, Rahmin Talib Husain}

meningkatkan pengertian pada masyarakat dan pihak terkait dengan program serta kegiatan ini sangat menentukan ketertarikan masyarakat untuk berperan dan terlibat dalam program pemberdayaan yang dilakukan.

Kedua, diversifikasi dan inovasi produk kerajinan anyaman yang juga masih rendah. Ibu rumah tangga miskin yang menjadi sasaran utama dampingan ini, dalam membuat produk anyaman masih sangat terbatas dan terfokus pada produk kerajinan anyaman tikar dan tas sederhana, belum berani mencoba bentuk produk anyaman lainnya yang lebih menarik, unik dan sesuai kebutuhan pasar.

Ketiga, usaha kerajinan yang ditekuni masih bersifat industri rumah, belum ada pengembangan produksi pada usaha dalam skala luas, meskipun didukung dengan ketersediaan bahan baku mendong (tiohu) yang mudah didapat dan dibudidayakan serta ditunjang dengan keahlian yang terampil dalam mengayam.

Keempat, adanya budaya meniru (plagiat) bentuk produk diantara ibu rumah tangga miskin yang menjadi perajin masih ditolerir, karena selama ini produk kerajinan yang dihasilkan sebagian besar hanya dalam satu produk kerajinan anyaman tikar.

Kelima, keterbatasan modal dalam mengembangkan usahanya, karena adanya sistem peminjaman modal yang dan tidak adanya koperasi di desa tersebut. Hal ini berakibat pada keterbatasan ibu-ibu rumah tangga miskin dalam menghasilkan produk kerajinan dalam jumlah yang banyak. Sementara dalam membuat produk kerajinan ini memiliki nilai jual yang tinggi membutuhkan modal dalam membeli bahan baku pendukung seperti: karton, cat warna, kain, dan lain-lain. Mengingat sifat bahan baku utama mendong (tiohu) yang tidak kuat untuk konstruksi dasar produk kerajinan.

Keenam, penghasilan ibu rumah tangga miskin sebagai pengrajin usaha kerajinan ini tidak sebanding dengan waktu dan tenaganya, karena harga jual dari produk kerajinan yang dibuat selama ini berbentuk tikar atau tas sederhana dibeli masyarakat dengan harga yang sangat rendah yaitu berkisar antara Rp. 15.000 s/d Rp. 25.00o. Sementara untuk menghasilkan satu produk kerajinan tersebut membutuhkan waktu yang lama antara 3 hari sampai seminggu. Tentunya, hal ini yang membuat ibu rumah tangga miskin yang menjadi sasaran dampingan, kurang termotivasi mengembangkan usaha kerajinan ini dan sebagian besar mereka hanya menjadikannya sebagai pengisi waktu luang, jika tidak ada pekerjaan rumah tangga yang dikerjakan.

\section{Analisis Eksternal}

Analisis eksternal dilakukan untuk mengidentifikasi peluang (opportunity) dan tantangan (threat) dalam melakukan program dampingan. Adapun peluang dan tantangan yang akan muncul yaitu:

\section{Peluang (Opportunity)}

Berdasarkan kekuatan dan kelemahan yang dimiliki dalam program pemberdayaan yang dilakukan, dapat diidentifikasi yang menjadi peluang dalam mengembangkan usaha kerajinan tangan anyaman mendong (mohalamu tiohu) di Desa Bulotalangi Timur Bone Bolango yaitu:

Pertama, adanya inovasi dari desain berbagai jenis produk kerajinan anyaman mendong yang unik dan menarik akan selalu diminati pasar, karena memiliki keunikan dan kekhasannya sebagai produk kerajinan anyaman tangan yang hanya dilakukan secara manual. Kedua, dengan adanya desain produk jenis kerajinan anyaman mendong yang unik dan menarik tentunya akan berdampak pada daya beli pasar meningkat dan kemungkinan pasar luar negeri terbuka lebar. Ketiga, sifat bahan baku utama dari tanaman mendong (tiohu) yang memiliki tekstur mudah dibentuk dan diberi warna yang menarik memiliki kemampuan untuk mengikuti trend yang sifatnya situasional.

\section{Tantangan (Threat)}

Tantangan yang dihadapi dalam mengembangkan usaha kerajinan tangan anyaman mendong (mohalamu tiohu) di Desa Bulotalangi Timur Bone Bolango yaitu: Pertama, ibu rumah tangga miskin yang menjadi sasaran dampingan, selain sebagai pengrajin juga bekerja sebagai ibu rumah tangga yang melaksanakan tugas rumah dan mengurus keluarganya mengakibatkan terhambatnya 


\section{JPPM (Jurnal Pendidikan dan Pemberdayaan Masyarakat), 6 (1), 2019 - 73}

Lian Gafar Otaya, Siti Asiah Tjabolo, Rahmin Talib Husain

proses produksi kerajinan anyaman mendong dalam jumlah banyak dengan waktu produksi yang tidak efisien atau membutuhkan waktu yang lama.

Kedua, berkembangnya produk kerajinan anyaman yang berkualitas baik, kuat dan tahan lama yaitu berbahan lain seperti: pandan, rotan, dan bambu, berakibat pada menurunnya daya beli masyarakat dan kurang tertarik dengan produk kerajinan tangan anyaman mendong (mohalamu tiohu). Mengingat sifat bahan mendong (tiohu) tidak sekuat bahan rotan ataupun bambu bahkan dari bahan komposit seperti plastik dan logam, serta berbahan kulit yang mengakibatkan penurunan nilai jual dari pada nilai estetika. Ketiga, sifat tekstur bahan mendong (tiohu) yang dalam pengerjaannya dianyam dengan menggunakan tangan, tidak dapat digantikan dengan mesin untuk mengejar jumlah produksi yang besar.

Strategi Pencapaian

Berdasarkan hasil analisis internal dan eksternal yang telah dikemukakan tersebut, secara esensial disimpulkan bahwa dalam memberdayakan ibu rumah tangga miskin di Desa Bulotalangi Timur melalui pengembangan usaha kerajinan tangan khas Gorontalo "mohalamo tiohu" diperlukan adanya pembinaan yang berkelanjutan bagi ibu rumah tangga miskin yang menjadi sasaran utama dampingan, khususnya mengenai kemampuan berinovasi menciptakan berbagai jenis produk kerajinan anyaman yang memiliki nilai jual yang tinggi melalui berbagai strategi pemberdayaan yang sesuai dengan kondisi dan kebutuhannya yaitu:

Pertama, strategi yang dilakukan melalui kegiatan pelatihan yang diberikan kepada ibu rumah tangga miskin yang menjadi sasaran utama dampingan seperti: pelatihan kemandirian menjadi masyarakat mandiri; dan pelatihan atau bimbingan secara terus menerus, menciptakan inovasi baru dalam desain produk anyaman mendong sehingga lebih variatif. Beberapa studi telah menunjukkan banyak manfaat yang diperoleh dari pelatihan diantaranya Blattman, Fiala, \& Martinez (2013), Hansen (2015), Frese, Gielnik, \& Mensmann (2016) menyatakan bahwa pelatihan memiliki potensi untuk berkontribusi nyata dalam memperkuat kemampuan manusia dan mempromosikan tindakan yang dapat mengubah status masa depannya sebagai penerima pelatihan. Meskipun hasil pelatihan perlu ditafsirkan dengan hati-hati karena ukuran sampel kecil dari orang-orang yang menerima pelatihan. Walton (2014) pelatihan akan memberikan hasil konsisten dalam waktu jangka waktu pendek jika dilaksanakan secara "bijaksana" dalam memberikan pengaruh secara psikologis bagi penerima pelatihan yang didukung dengan penguatan kelembagaan ekonomi yang memadai. Namun oleh Mckenzie \& Woodruff (2014) perlu dilakukan pengujian terhadap berbagai bentuk pelatihan untuk menentukan unsur-unsur dari usaha pemberian keterampilan yang memiliki pengaruh terbesar dan apakah pelatihan harus fokus pada pembentukan kepribadian dalam berwirausaha.

Kedua, berusaha menumbuhkan kepercayaan masyarakat terhadap program pemberdayaan ini, karena kepercayaan merupakan modal utama untuk mendapatkan dukungan terhadap keberhasilan suatu program pemberdayaan. Sebuah kepercayaan akan bisa didapatkan bila dibangun dengan keterbukaan. Keterbukaan yang dimaksud adalah kemauan untuk berpartisipasi sesuai dengan kesadarannya. Selain itu adanya pengetahuan, persepsi dan sikap yang baik akan memunculkan tindakan yang sesuai yaitu adanya inisiatif yang muncul dari masyarakat sendiri (Ristianasari, Muljono, \& Gani, 2013). Dengan adanya inisiatif Ibu rumah tangga miskin mereka bisa memutuskan sendiri hal apa yang harus mereka lakukan berkaitan dengan pengembangan usaha kerajinan ini dalam meningkatkan kesejahteraan hidup mereka.

Ketiga, pemberian modal usaha kepada semua kelompok ibu rumah tangga miskin sebagai pengrajin dan dibekali dengan pengetahuan berwirausaha yang baik. Hal ini sejalan dengan temuan Drexler, Fischer, \& Schoar (2014) bahwa untuk mendukung pengembangan sebuah usaha diperlukan adanya sumber daya keuangan (microcredits) atau dengan pengetahuan berwirausaha yang lebih baik. Selain itu oleh Ahmadi (2012) menyatakan modal manusia adalah pengeta- 


\section{JPPM (Jurnal Pendidikan dan Pemberdayaan Masyarakat), 6 (1), 2019 - 74}

Lian Gafar Otaya, Siti Asiah Tjabolo, Rahmin Talib Husain

huan, keterampilan, dan motivasi yang dimiliki oleh masyarakat miskin sebagai modal untuk keluar dari kemiskinan secara berkelanjutan dan kemampuan itu diperoleh melalui proses pendidikan atau pelatihan. Tentunya ini sangat tergantung dari peran lembaga pemberdayaan melalui program pendampingan.

Keempat, membangun kemandirian ibu rumah tangga miskin sebagai sasaran utama dampingan dalam mengembangkan usaha kerajinannya yang mampu merubah hidupnya menjadi lebih baik sesuai dengan yang diharapkan. Hal ini sejalan dengan temuan Pratama (2014) bahwa peran lembaga pemberdayaan yang menjadikan dirinya sebagai mediator, fasilitator sekaligus sebagai perwakilan bagi masyarakat yang mengupayakan agar masyarakat sebagai penerima program dampingan berdaya dalam membangun hidup mereka secara layak dan mandiri.

Keempat, hendaknya mengotimalkan partisipasi aktif dari ibu rumah tangga itu sendiri, untuk ikut terlibat dalam setiap prosesnya mulai dari perencanaan, pelaksanaan maupun implementasi dan evaluasi serta tindak lanjut pengambilan keputusan perbaikan ke arah yang lebih baik. Seperti yang dikemukakan Imron, Soeaidy, \& Ribawanto, (2011) di dalam pengembangan kapasitas kelembagaan masyarakat sasaran pemberdayaan atau anggota dari kelompok usaha bersama seharusnya memiliki keberanian untuk mengungkapkan berbagai permasalahan-permasalahan yang dialami kepada pendamping lapangan bukan sebaliknya, sehingga dapat diketahui bagaimana cara untuk menyelesaikannya. Selain itu, menurut Zuliyah (2018) berbagai upaya pemberdayaan yang dilakukan pada masyarakat desa tanpa didukung kemampuan maupun kemauan untuk maju menjadi masyarakat yang mandiri akan kurang bermanfaat, sehingga bantuan ekonomis saja tidak cukup. Jika bantuan tersebut habis, maka kegiatan tersebut akan terhenti. Menurut Theresia, Andini, Nugraha, \& Mardikanto (2014, p. 93) bahwa dengan memberdayakan masyarakat berarti memandirikan masyarakat melalui perwujudkan potensi kemampuan yang mereka miliki. Oleh karena itu, untuk menunjang keberhasilan pemberdayaan ibu rumah tangga miskin di Desa Bulotalangi Timur melalui usaha kerajinan tangan khas Gorontalo "mohalamo tiohu" ini sangat tergantung dari kemandirian mereka untuk mengerahkan segala kemampuannya menjadi masyarakat mandiri yang tidak hanya memiliki kemampuan saja dan menikmati hasilnya, namun juga memiliki kemauan untuk mengembangkannya secara terus-menerus.

Dengan demikian pemberdayaan Ibu rumah tangga miskin penting untuk dilakukan. Menurut Hermawan \& Suryono, (2016) dengan adanya pemberdayaan masyarakat, mereka mampu menggali permasalahan, mampu mengidentifikasi, merencanakan sekaligus mencari pemecahan masalah karena mereka tahu persis apa yang mereka butuhkan dan harapkan.

\section{SIMPULAN}

Pemberdayaan ibu rumah tangga miskin di Desa Bulotalangi Timur melalui usaha kerajinan tangan khas Gorontalo "mohalamo tiohu" diperlukan suatu analisis kebutuhan untuk mengetahui gambaran mengenai potensi yang dimiliki sentra industri dan peluang yang mungkin terjadi (analisa internal), serta permasalahan dan ancaman (analisa eksternal) yang perlu ditangani dan dipecahkan. Analisis ini juga bermanfaat pengembangan usaha ibu rumah tangga miskin untuk dapat menyusun strategi dalam menjalankan usahanya di masa yang akan datang berdasarkan permasalahan umum yang dihadapinya adalah pengetahuan tentang pemasaran dan desain produk masih sangat terbatas, sehingga diversifikasi dan inovasi produk kerajinan ini juga masih rendah. Selain itu masih bersifat industri rumah dan budaya meniru produk di antara perajin hanya dalam satu produk kerajinan anyaman tikar dan tas sederhana padahal mereka tergolong terampil dalam membuat berbagai jenis kerajinan tangan dalam jumlah banyak, adanya sistem peminjaman modal yang rumit karena tidak adanya koperasi di desa tersebut, penghasilan perajin tidak sebanding dengan waktu dan tenaganya, padahal sifat bahan memiliki kemampuan untuk mengikuti trend dengan teknik dasar menganyam yang hanya dapat dilakukan 


\section{JPPM (Jurnal Pendidikan dan Pemberdayaan Masyarakat), 6 (1), 2019 - 75 \\ Lian Gafar Otaya, Siti Asiah Tjabolo, Rahmin Talib Husain}

secara manual, memiliki tampilan visual (tekstur) pola anyaman yang indah dan bervariasi. Untuk pengembangan dan keberlanjutan usaha diperlukan adanya pembinaan secara berkala pada ibu rumah tangga pengrajin dan pemberian modal usaha yang diberikan secara merata kepada semua kelompok ibu rumah tangga miskin sebagai pengrajin, upaya untuk mempatenkan hasil karya mereka perlu dilakukan dan menggalakkan kecintaan masyarakat terhadap produk kerajinan tersebut. Selain itu, Pemerintah perlu meningkatkan penyelenggaraan pendidikan dan pelatihan teknis yang bertujuan untuk meningkatkan kualitas dan kuantitas, maupun pemasaran produk hasil kerajinan tersebut. Upaya ini dilakukan terutama sebagai terobosan pengembangan usaha kerajinan ini yang sedang mengalami stagnasi atau kurang diminati konsumen atau pasar.

\section{DAFTAR PUSTAKA}

Ahmadi, R. (2012). Pemberdayaan masyarakat miskin: pendekatan modal manusia. Jurnal Administrasi Publik, 10(2), 16-31.

Alvarez, K., van Leeuwen, E., MontenegroMontenegro, E., \& van Vugt, M. (2018). Empowering the poor: A field study of the social psychological consequences of receiving autonomy or dependency aid in Panama. British Journal of Social Psychology, 57(2), 327-345. https://doi.org/10.1111/bjso.12234

Armoyu, M. (2013). Pemberdayaan masyarakat miskin melalui pendekatan modal sosial. Jurnal Lisan Al-Hal, 5(2), 281-299.

Asfi, N., \& Wijaya, H. B. (2015). Efektivitas pemberdayaan masyarakat dalam pengentasan kemiskinan pada program gerdu kempling di Kelurahan Kemijen Kota Semarang. JUrnal Teknik PWK, 4(2), 253-268. Retrieved from http://ejournal-

s1.undip.ac.id/index.php/pwk

Asril, D. (2013). Pemberdayaan masyarakat miskin melalui pengembangan sistem pendukung bagi usaha mikro kecil menengah (UMKM) Kota Medan.
Jurnal Perspektif, 6(2), 124-136.

Bogdan, R. C., \& Biklen, S. K. (2006). Qualitative research for education an introduction to theory and methods. Boston: Aliyn and Bacon, Inc.

Blattman, C., Fiala, N., \& Martinez, S. (2013). Generating skilled self-employment in developing countries: experimental evidence from Uganda *. Quarterly Journal of Economics Abstract:, (510), 139.

Chevalier, J. M., \& Buckles, D. J. (2013). Participatory action research: Theory and methods for engaged inquiry. New York: Routledge.

Darwis, R. S. (2016). Membangun desain dan model action research dalam studi dan aksi pemberdayaan masyarakat. KOMUNIKA: Jurnal Dakwah dan Komunikasi, 10(1), 142-153.

Drexler, B. A., Fischer, G., \& Schoar, A. (2014). Keeping it simple: Financial literacy and rules of thumb. American Economic Journal: Applied Economics, 6(2), 1-31. Retrieved from http://dx.doi.org/10.1257/app.6.2.1

Frese, M., Gielnik, M. M., \& Mensmann, M. (2016). Psychological training for entrepreneurs to take action: contributing to poverty reduction in developing countries. Psychological Science, 25(3), 196-202. https://doi.org/10.1177/o9637214166369 57.

Gay, L., Mills, G. E., \& Airasian, P. (2012). Educational research: competencies for analysis and applications. Boston: Pearson Education, Inc.

Hadiyanti, P. (2011). Penerapan strategi pemberdayaan masyarakat melalui program keterampilan produktif di PKBM Rawasari. Jurnal Ilmiah Visi, 6(2), 126-135.

Hansen, N. (2015). The development of psychological capacity for action: The empowering effect of a microfinance programme on women in Sri Lanka. Journal of Social Issues, 71(3), 597-613. 
JPPM (Jurnal Pendidikan dan Pemberdayaan Masyarakat), 6 (1), 2019 - 76

Lian Gafar Otaya, Siti Asiah Tjabolo, Rahmin Talib Husain

https://doi.org/10.1111/josi.12130

Harahap, F. (2018). Dampak pemberdayaan masyarakat melalui program biogas dalam mewujudkan kemandirian energi. JPPM (Jurnal Pendidikan dan Pemberdayaan Masyarakat), 5(1), 41-50. doi:https://doi.org/10.21831/jppm.v5i1.1 8634

Hermawan, Y., \& Suryono, Y. (2016). Partisipasi masyarakat dalam penyelenggaraan program-program pusat kegiatan belajar masyarakat Ngudi Kapinteran. JPPM (Jurnal Pendidikan dan Pemberdayaan Masyarakat), 3(1), 97-108. doi:https://doi.org/10.21831/jppm.v3i1.8 111

Imron, I., Soeaidy, M. S., \& Ribawanto, H. (2011). Pemberdayaan masyarakat miskin melalui kelompok usaha bersama (Studi pada kelompok usaha bersama di Desa Dawuhan, Kecamatan Poncokusumo, Kabupaten Malang). Jurnal Administrasi Publik (JAP), 2(3), 485-491.

Kemmis, S., McTaggart, R., \& Nixon, R. (2013). The action research planner: Doing critical participatory action research. New York: Springer Science \& Business Media.

Kidwai, H., Iyengar, R., Witenstein, M. A., Byker, E. J., \& Setty, R. (Eds.). (2017). Participatory action research and educational development: South Asian perspectives. Palgrave Macmillan: Springer.

Koch, T., Selim, P., \& Kralik, D. (2002). Enhancing lives through the development of a community-based participatory action research programme. Journal of Clinical Nursing, 11, 109-117.

Macdonald, C. (2012). Understanding participatory action research: a qualitative research methodology option. Canadian Journal of Action Research, 13(2), 34-50.

Mckenzie, D., \& Woodruff, C. (2014). What are we learning from business training and entrepreneurship evaluations around the developing world? The Work Bank Research Observer, 29(1), 48-82.

https://doi.org/10.1093/wbro/lktoo7.

Miles, M. B., Huberman, A. M., \& Saldana, J. (2014). Qualitative data analysis: $A$ methods sourcebook. Thousand Oaks, California: Sage Publications, Inc.

Pratama, B. R. S. (2014). Peran lembaga rumah pemberdayaan masyarakat melalui pendampingan keluarga miskin ( $\left.P_{2} K M\right)$ Di Pamulang Permai I Tangerang Selatan. UIN Syarif Hidayatullah.

Prihatin, S. N., \& Fauziah, L. (2013). Pemberdayaan ekonomi masyarakat miskin berbasis UPKU Panca Usaha di Desa Mojoruntut Kecamatan Krembung. Jurnal Kebijakan Dan Manajemen Publik (JKMP), 1(2), 111-236.

Ras, A. (2013). Pemberdayaan masyarakat sebagai upaya pengentasan kemiskinan. Socius, XIV, 56-63.

Ristianasari, Muljono, P., \& Gani, D. S. (2013). Dampak program pemberdayaan model desa konservasi terhadap kemandirian masyarakat: kasus di taman nasional bukit barisan selatan Lampung. Jurnal Penelitian Dan Ekonomi Kehutanan, 10(3), 173-185.

Theresia, A., Andini, K. S., Nugraha, P. G., \& Mardikanto, T. (2014). Pembangunan berbasis masyarakat: acuan bagi praktisi, akademisi, dan pemerhati pengembangan masyarakat. Penerbit Alfabeta.

Wahyuni, D. (2018). Strategi pemberdayaan masyarakat dalam pengembangan Desa Wisata Nglanggeran. Jurnal Aspirasi, 9(1), 85-102.

Walton, G. M. (2014). The new science of wise psychological interventions. Psychological Science, 23(1), 73-82. https://doi.org/10.1177/096372141351285 6.

Wesa, A., \& Suryono, Y. (2014). Kesejahteraan ekonomi masyarakat peserta pelatihan 
JPPM (Jurnal Pendidikan dan Pemberdayaan Masyarakat), 6 (1), 2019 - 77 Lian Gafar Otaya, Siti Asiah Tjabolo, Rahmin Talib Husain

kelompok prakoperasi di Kecamatan Namlea Kabupaten Buru. JPPM (Jurnal Pendidikan dan Pemberdayaan Masyarakat), $1(2), \quad 149 \quad$ - 159. doi:https://doi.org/10.21831/jppm.vii2.2 685
Zuliyah, S. (2018). Strategi pemberdayaan masyarakat desa dalam menunjang pembangunan daerah. Journal of Rural and Development, 1(2), 151-16o. 